This item is the archived peer-reviewed author-version of:

\title{
Planning and law in evolving governance
}

\section{Reference:}

Van Assche Kristof, Beunen Raoul, Smit Anneke, Verschraegen Gert.- Planning and law in evolving governance Evolutionary governance theory : theory and applications / Beunen, Raoul [edit.]; et al. - ISBN 978-3-319-12273-1 - Heidelberg, Springer, 2015, p. 37-55

Full text (Publishers DOI): http://dx.doi.org/10.1007/978-3-319-12274-8_3

Handle/Permalink: http://hdl.handle.net/10067/1210600151162165141 


\title{
Planning and law in evolving governance
}

\author{
Kristof Van Assche, \\ University of Alberta, Faculty of Extension; Bonn University, ZEF/ Centre for Development \\ Research \\ Raoul Beunen, \\ Wageningen University, Strategic Communication Group \\ Anneke Smit, \\ Windsor University, Faculty of Law \\ Gert Verschraegen, \\ University of Antwerp, Dept of Sociology
}

\section{Introduction}

Law plays an important role in contemporary society. Its main function, in social systems terms, is stabilizing expectations. Each community has its own legal system and the roles of law, the way in which expectations are institutionalized, and the impact of particular institutions can largely vary. This chapter explores the roles of law from an evolutionary perspective. Particular attention is given to its relation with spatial planning, which we define as the coordination of practices and policies effecting spatial organization. Planning plays an important role in governance. It relates to the attempts and desires to develop into certain directions and the strategies deployed to do so. Planning in this perspective is not restricted to public organizations, but includes governments, markets and civil society. This chapter seeks to develop a theoretical 
framework that can be used to gain a better understanding of the roles of law in the evolution of governance and the way in which these delineate a particular space for planning in a society. Each society or community has a different form of planning, including different roles of law in planning. The evolution of governance in communities, and the specific linkages between law, economy and politics that have been forged in specific evolutionary paths, frame the possibilities for planning and the potential roles of law. We propose to distinguish three main roles of law in planning: law can enable, delimit and codify planning. How these three roles play out in a particular context, and how they relate, depends on the unique evolutionary path of each community.

Our perspective combines insights from legal and political anthropology with social systems theory. An insight shared by these theoretical sources is the embedding of formal institutions, the formal coordination mechanisms such as laws and plans, in informal institutions. Law emerged out of informality, is sustained by it, and is continuously transformed by it. The same applies to plans. Laws and plans always function in an environment of other formal institutions that are similarly affected by worlds of informalities (Greif 2006; Ellickson 1991; Scott 1998; Von Benda-Beckman 2002; Hayoz and Giordano 2013). When communities evolve, various informal coordination mechanisms evolve, and with that, the spaces for formal coordination mechanisms, like law and planning, and the roles of law in planning become clear.

In the following sections, we first present the building blocks of our theoretical framework. We then present four scenarios, which are based on our observations of governance evolutions in different parts of the world. The scenarios are fictional yet realistic stories that allow us to present a variety of evolutionary mechanisms, and the interplay between delimitation, enabling and codification. We use these scenarios to introduce a set of principles regarding that interplay. 


\section{Theoretical Framework}

\subsection{Basic notions of planning and law in a systems analysis}

Law is the function system that stabilizes generalized expectations in society (Luhmann 2004; King and Thornhill 2003; Teubner 1988). It is not the rules themselves which are essential, but rather the expectation that the actions of all actors are guided by these rules, and that these actions are therefore more or less predictable (Luhmann 2004; North 2005). This is also known as a "rule of law" culture (Stein 2009). When a breach of the expectations generalized by law occurs, the legal system counter-factually reaffirms those expectations (Teubner 1988). By maintaining counterfactual expectations over time (laws will be broken, but the law remains), law provides a consistent and seemingly predictable social environment for actors.

Politics is the function system in which collectively binding decisions are taken (Luhmann 1990, Luhmann 1995). Power is an essential medium in politics, since calculations on the possibility or impossibility of a collective decision are essentially a power calculus: do we have the votes, or other means to broker it? Some political decisions can be codified as law, making non- compliance illegal. This also applies to plans: some can be turned into law, whereby noncompliance with the spatial vision is illegal. Other visions can remain policies. The real effects of non-compliance cannot be derived from this distinction, however. Implementation and enforcement are not guaranteed by legal status and in any community there might be a diversity of mechanisms that favor compliance with plans-as-policies (Beunen and Duineveld 2010).

Planning can be considered a sub-system of politics, since it aims to produce collectively binding decisions in the form of plans, policies, designs or laws. Planning as an activity is also 
embedded in science, law, economics and other functional domains, but it can never be reduced to any of these, since the basic premise is coordination, i.e. forging a collective decision or a coherent whole of decisions implied in a vision (Beunen and Van Assche 2013; van Dijk and Beunen 2009). Planning is an ongoing process of coordination and an ongoing discussion on the rules of coordination (Van Assche and Verschraegen 2008). Planning does not necessarily and uniquely take place in governmental organizations carrying the label 'planning', but in various organizations and by means of various institutions crossing the public/private divide (Allmendinger 2002; Hillier 2002). Public/private partnerships (PPP), for example, are one increasingly common space in which planning takes place outside of formal "planning" departments (Dalla Longa 2011).

This brief systems theoretical discussion already reveals a few things about the roles of law in governance and planning. First of all, planning cannot be expected to produce a perfect and perfectly neutral organization of space, and such cannot be expected from law either. Law can help planning in various ways to stabilize expectations, to smoothen decision- making and the implementation of decisions, but the resulting space will remain a space of political struggle. Secondly, and relatedly: politics cannot oversee society, it cannot entirely predict the effects and uses of law, and law cannot predict what the next political move will be. Law and politics complement each other; they cannot replace each other. In planning, as a political domain, this means that law will always reappear in new forms and roles: shifts in politics will bring new forms of planning and new uses of law. Further, new laws will have effects in governance that are unpredictable, because of political and economic uses of law, and because of the partial opacity of law for politics. 
Besides the structural relation between law and politics, there is another reason for the dynamism and variation in roles of law in governance: the dialectics between formal and informal institutions. Formal institutions, such as laws, can only be understood as emerging from and functioning in an environment of informal institutions (Greif 2006; Ellickson 1991). Concurrently, the crystallization of law also produces shifts in informal institutions (Van Assche et al. 2012a). Laws can become both offensive and defensive tools in political and economic games, e.g. in planning and development strategies. Understanding the role of laws, then, is about understanding the dialectics of formal and informal institutions.

\subsection{Three Roles of Law in Governance}

Drawing on a combination of anthropological (Donovan 2008; Von Benda-Beckman 2002; Scott 1998; Pottage 2004; Conley and O'Barr 1993; Bohannan 1969), geographical (Braverman 2011; Platt 2004; Delaney et al. 2001 Blomley and Clark 1990; Grossfeld 1983), institutionalist (Seabright 2010; North 2005; Ostrom 2005; de Soto 2000; Easterly 2006; Thelen 1999) and systems theoretical (Luhmann 1995; Luhmann 2004; Seidl 2005; Teubner 1989; Stichweh 2000) readings, and building on the notions introduced above, we propose to distinguish three functions of law in governance: law can enable, delimit and codify planning.

In democracies, planning needs to be legal to be carried out by a state that is simultaneously law-giving. The powers to coordinate spatial organization, for example by making plans and enforcing their implementation or compliance, need to be vested somewhere by law. Thus, it can be said that laws uphold or enable planning. A superficial acquaintance with US and European planning traditions already evokes the different relative importance of this function in different places (Peterson 2003; Blaesser and Weinstein 1989). In the US, more than in Europe, planning 
by governments evolved in a cloud of debate on the limits of governmental power (Jacobs 2004; Ohm 2000; Fischler 1998; Fischel 1987). The legal competencies of local governments are to a great extent defined by state statutes. Most forms of spatial planning have proven to be within reach of litigation when politics shift to the right or when entrepreneurial lawyers seek out clients in previously planning-friendly areas (Peterson 2003; Makielski 1966). Every planning decision and document that is not directly grounded in considerations of safety, health and well- being can be easily disputed (Platt 2004). Further, instead of litigation the same political shifts can inspire willful neglect of comprehensive plans, visions, and zoning plans. At that point these become dead institutions (Van Assche et al. 2012a). At the same time, both political and demographic shifts can create the need for new planning laws, which guide necessary changes to urban landscapes. Extreme population loss in post-industrial American cities such as Detroit and Cincinnati has led to calls for radical planning laws which will enable large-scale urban "shrinkage" (Binelli 2012; Gallagher 2010). While countless informal or localized efforts have been launched to address the depopulation crisis, it is argued that a larger-scale, and formalized, urban plan is needed to manage such a re-creation.

In western Europe, most countries have assigned planning powers to several levels or tiers of government (Salet et al. 2003). In many cases, there are national-level planning organizations or departments where coordination of local and regional planning is carried out. Responsibilities and powers of the various levels of politics and administration are laid down in laws regarding spatial planning. More easily than in the US, new national planning laws can reshuffle the planning powers of different levels of government, and change the balance between politics and administration. Even so, significant changes in the distribution of planning powers will require changes in national planning law. 
Law can also delimit planning. Planning, whether carried out by governmental actors or by others, can embody or produce a vision of the common good that is not shared by everyone (Hillier 2002). Planning can also negatively affect values in society that were encapsulated in other laws (Delaney et al. 2001). Plans can have effects that are considered detrimental to society or to individuals pursuing something that is within the scope of their protected liberties (Elliott 2008). These different goods and values are often protected by laws which in turn delimit planning. Property rights are the classic example, but environmental law, laws on religious freedom, freedom of speech, and others can also be invoked against planning schemes (Posner 2003; Stallworthy 2002; Gel'man 2004; Gerber 1999; Schlager and Ostrom 1992). Constitutional law can be relied upon when planning is perceived to overstep its boundaries, and procedural law is in practice the most common legal obstacle to plan implementation (Reynolds 2010).

Delimitation and enabling at first seem to be negatively correlated. If few planning powers are enabled, delimitation is strict. However, planning powers can be far reaching yet clearly localized and delimited: only at a particular level of government, only for specific topics, or only under certain conditions (Jacobs 2004; de Soto 2000). Moreover, the same set of enabling and delimiting laws can produce different results in different places. In the past decade the Netherlands saw a supposed withdrawal of the government's role in planning, but de facto it simply meant a shift of planning power and activities from national and regional to the municipal level and a stronger emphasis on legal tools for coordination. In France, traditionally very weak rural municipalities were forced into amalgamations and cooperation at sub-regional level. Some of these new actors continued a no-planning regime, now with more consequences, while others discovered and cultivated planning ambitions (Waterhout et al. 2013; cf. Mansuri and Rao 2012). 
Thirdly law can codify planning. Certain plans, visions, and planning policies acquire the character of law. In the US, the zoning plan and the local land use ordinances are usually local law, while in the Netherlands, a much more detailed zoning plan is the only document in a complex planning system that is legally binding for citizens (Ford 2010; Needham 2006). In the USSR, all plans were simultaneously law, and achieving the goals embedded in the plans was considered a legal obligation (Allina - Pisano 2008; Verdery 2003; Van Assche 2013). In each of these cases, the legal status does or did not entail automatic implementation. Legal codification of planning documents does not mean that these become the most influential documents in a planning system. However, it does indicate that law is often perceived as a necessary tool towards plan implementation.

One can surmise that codification will be relatively more important where enabling powers are scarce and delimitation is strict (cf. Platt 2004; Jacobs 2004). If governmental interference in the coordination of spatial organization is considered an exception and barely accepted in the community, the only tool to enforce a plan is probably the law, since this is likely to be the only tool of government that is accepted in such an environment. However, in evolving governance, the power of codification and the effects of previously codified plans will change concomitantly (Teubner 1989; Von Benda-Beckman 2002; Bishwapriya 2012). We argue that these three functions of law in planning can be discerned in every community, but that the relative importance of each function will differ.

\section{Planning and interwoven functions of law: four scenarios}

In this section we further explore the specificity of interwoven functions of law in planning in governance evolutions by looking at four possible governance scenarios. In these scenarios 
planning played a role and the three functions of law can be illustrated in their co- evolution. Each scenario is a collage of real- world situations, as a series of events that could unroll and did unroll many times before. The scenarios briefly show that certain forms of planning become possible and more likely in particular evolutions and that same evolutions make it more likely for a particular role of law to appear as significant.

\section{Scenario 1: A small American town ${ }^{1}$}

This scenario narrates the story of a small American town where a long time ago a local planner, with the help of a volunteer organization and the then-active community, had drawn up a comprehensive plan. After reading Randall Arendt, a famous ecologically inspired planner/ designer (e.g. 1999), the local planner had convinced the township council that there ought to be a harmonization between the land use ordinance and the comprehensive plan, so that the goals of the plan could be consistently envisioned. However, 16 years pass, the comprehensive plan gathers dust, and the land use ordinance and zoning plan are slowly changed, in a piecemeal accumulation of details. The locals lost trust in 'planning' since the comprehensive plan 'didn't do much'. The land use ordinance is legally binding and state statutes make it possible to give the comprehensive plan this same legal status, but this didn't happen because people believed one plan was enough.

So, the comprehensive plan is the reflection of a vision for the community, a design, and the zoning plan is legally codified. The design itself, in the visible unity of the comprehensive plan, is not codified, although state law permits this option. When after a while many locals forget about the intimate connection between the comprehensive plan and the zoning plan, zoning

\footnotetext{
${ }^{1}$ This scenario is inspired by experiences with the Minnesota Design Team, a volunteer- expert organization assisting local communities with planning and design, in the period 2006-2012. It is further underpinned by our research for a book on lakeside living in North America (Radomski and Van Assche 2014).
} 
changes are more easily accepted and a local tradition of very flexible interpretation of zoning and land use requirements is formed. Then the economic crisis hits, a local tea party committee forms and overthrows the moderate and pro- environment republicans in the township government.

A developer, in fact the cousin of a local farmer, rapidly buys land around a lake and unexpectedly comes up with a detailed plan for a condo- style development right on the water, in flagrant contradiction with all of local plans and with state environmental regulations. The lake is classified as natural lake by the department of natural resources, and townships have no planning authority over the first 500 feet away from the water. One local environmentalist refers to the comprehensive plan, but he is quickly dismissed. One township board member refers to the land use ordinance, but is rebuffed by another member who has heard that the developer will sue if he cannot start construction immediately. A discussion ensues and nobody is sure, given the informal jurisprudence of flexible planning, if they can make a case in court. Nobody is fully in favor of the development, but it is feared that a court case cannot be afforded and would be very divisive in the already unstable political environment.

The township does not have its own lawyer and the board members prefer not to consult the mistrusted county attorney but instead talk to a retired lawyer with a home on the lake. The man cringes when he hears of the condos soon spoiling his view, but, without much investigation says he 'never heard of a township successfully challenging a big developer', especially since almost everything was permitted in the last decade or so. The township board therefore believes that suddenly restarting 'planning' and objecting to the development would be unduly infringing on the property rights of the developer. They assume that law delimited their planning powers and that their legal plan has lost its 'teeth' because it has not been used for a while. These beliefs take 
root partly because of the isolation of the community and the lack of communication with higher-level authorities.

The environmentalist does talk to the county attorney, who informs the county planner. This county planner has friends at the department of natural resources, which happen to be under competent management and a state legislature that allows it to do its work, to enforce state laws and regulations. They know the developer, have their own attorney and a budget for litigation, and know that the developer does not stand a chance in court.

\section{Scenario 2: A western European regional government ${ }^{2}$.}

In a particular province a problem is signaled: water levels in the rivers are rising and neither the national government nor the municipalities seem to notice or care. The provincial planning department has always worked closely with the hydraulic engineers at public works and with the hydrologists at the environmental department and now decide to tell the provincial council that coordinated action, in fact a plan, is needed. It looks like many of the planned developments in the region are much more flood-prone than imagined. Developers and other investors own considerable acreage in areas which were designated for development, something which now looks risky. Municipalities, often close to developers, complain about over-regulation by the proposed provincial plan.

Provincial planning powers have been reduced recently, delegating more authority to the municipalities, but in the past, the province had never fully played the coordinative role it was entitled to. The proposed spatial plan, using water flows as the first ordering principle, is therefore still within the legal limits of its new authority. Still, two municipalities, both with neo-

\footnotetext{
${ }^{2}$ This scenario is inspired by our experiences in the Netherlands and Belgium in the period 1996-2014, as researcher and consultant for government; see e.g. Van Assche et al. 2012b, Duineveld et al. 2013, Duineveld et al. 2009, Assche 2006, Beunen 2010, Duineveld 2006.
} 
liberal mayors, go first to the minister, then to the court, to contest the provincial plan. The administrative court turns out to be heavily politicized and drags its feet. Two years pass and nothing happens. Citizens never complain, and the law possibly delimiting provincial planning power is administrative law, spanning the division of powers between levels of government. The discussion on local autonomy, however, is simultaneously driven by developers and their perceived property rights. In a situation where property rights are continuously remolded in planning games, and such planning is accepted, influencing planning becomes more rewarding for private parties.

The following spring, a dyke breaks, a new neighborhood is flooded, and the tone of the discussion changes. More people ask openly why the neighborhood was built there in the first place. An investigative journalist exposes links between developers and local governments, and mentions the provincial plan as a possible answer. The national government sees an opportunity, and reasserts its planning power by backing the provincial plan.

\section{Scenario 3: A Soviet kolkhoz ${ }^{3}$}

1970: in a Central Asian Soviet kolkhoz (collective farm) where 16,000 people live in two villages and a dozen hamlets, an abundance of plans, both economic and spatial, supposedly regulate its functioning. Many of these plans are codified as law: this includes the economic plan and its production targets and in many cases also the 'production' of houses, infrastructure, schools and so forth. The kolkhoz has an active director, with connections at the state capital and at regional levels. The plans are sometimes ignored, sometimes reinterpreted, sometimes changed after subtle negotiation. In the negotiation, the kolkhoz can co-create the law it is

\footnotetext{
${ }^{3}$ This scenario is inspired by our research on Soviet and post- Soviet planning in 2002- 2012 and by the collective experiences at ZEF/ Center for Development Research, Bonn University, in post- Soviet rural development in 20002012; see e.g. Van Assche 2013, Djanibekov et al. 2013, Van Assche and Djanibekov 2012, Van Assche et al. 2011)
} 
subjected to; it can be pleasant to receive orders to build a new school. One can say that the internal complexity of the kolkhoz makes it both opaque and useful for the higher planning authorities, and that it delimits planning attempts. The codification of too many plans as law, intended to enhance steering capacity, creates so many practical problems over the years that local management is forced to subvert or modify the plans. In the end, codification can be used to the advantage of various players, and central steering is eroded rather than enhanced.

Laws delimiting planning are not easily found, except for other plans that codify conflicting objectives and thus might create limitations. Higher authorities silently prioritize what they expected from the kolkhoz, so the higher ranking goals and plans delimit the impact of lower ranking ones. The enabling laws are enshrined in the USSR constitution, where planning laws appear not as an exceptional modification of property rights for of a common good, but rather as a key tool of the state to create Soviet Man and Soviet society.

Meanwhile, the kolkhoz, the people in the hamlets refuse to move to villages, which was part of plans favored by both kolkhoz management and higher authorities. The days of Stalin are over, and brutal solutions are out of the question. Moreover, these people are somehow related to people in management and to some others higher up. After long pondering, the kolkhoz manager strategically uses a grant to bring electricity and street lighting to the kolkhoz. He decides to spend the money in the villages, and this works well as bait for the people in hamlets scattered throughout the fields. Most of them move. A different law and a different plan (regarding electrification) in fact enable the implementation of the spatial plan.

Scenario 4: A sub-Saharan African village 4

\footnotetext{
${ }^{4}$ This scenario is mostly inspired by literature, e.g.Easterly 2006;Mansuri and Rao 2012; Ferguson 1994; Waters 2005; Brown et al. 2013; de Soto 2000. Further, it draws on conversations in 2010-2013 with the Africa- specialists
} 
In the village, nobody has title to her land. There is no land registry at this local level, although three EU grants were supposed to create an IT- driven land management system for the whole country. Registration only materializes around the capital and for some big plantations. There is a national law regarding spatial planning, dating from a period of socialist experimentation. It has been on the shelf for about 25 years. New projects are either private sector initiatives, NGO-driven, or focused on the capital. After some bad experiences with local chiefs and their cronies, western investors and the NGO community start to call for change. Change occurs: projects deemed important enough by the political elite are immediately codified as law. Thus, law officially enables planning, but does not provide any guidance at all; law does not delimit planning in any formal and predictable sense. Ad hoc codification of certain projects, backed by a real threat of violence by government militia, provides the level of tenure security that encouraged investors and at the same time maintains an attractive level of planning flexibility for those with political connections.

Then, a new national government comes in. They are more social-democratic in orientation, but inspired by Tony Blair's combination of free market principles and policies targeting collective goods. Since their political coalition is fragile, and they need to keep investors and NGO's on board, they avoid a potentially divisive debate on planning. Instead, they decide to take the old law enabling planning from the shelf. They also decide, inspired by an American NGO reading de Soto (de Soto 2000), that formalizing use rights, i.e. creating formal property rights, is the best way to protect and encourage investment by a much larger group of people. Some of the more enlightened elements in the new coalition envision a future where economic growth is locally driven, so the government has to become less dependent on outsiders. Later,

at ZEF/ Center for Development Research at Bonn University; project related in ZEF working papers 32, 41, 91, 99, 104, 110). 
when the economy is stronger and less dependent on a small group of foreigners, the government hopes to pursue a much more planning-intensive agenda. Currently, competent bureaucrats are already developing various plans and policies, but they are to be kept secret for the time being.

The combination of revived planning and generalized property rights proves more difficult than expected. Many people feel they are losing the fight for formalization of their use rights, and the winners are seen as either darlings of the donor community or friends of the elite. Several losers appeal to the courts, but the government, in principle in favor of independent courts, finds the property rights project too big to fail, and pressures judges. This leaks out, trust in the courts falters, and a violent uprising starts, only to subside after the government steps down and is replaced by a neo-liberal one. The draft plans and policies come to the surface, and the image of the previous pro-planning and pro-property rights government is tainted even more. In the public imagination, both planning and property rights are now seen as schemes serving the elites. The law enabling planning is revoked, and assigning formal property rights once again becomes an ad hoc process. Reversing the situation becomes harder than ever before.

\section{Spaces for planning and functions of law in governance evolutions}

These four scenarios illustrate the interaction between the functions of law as enabling, delimiting and codifying planning in governance evolutions. In this section we further explore the ways in which the functions of law in governance can change. We first pay attention to the dimension of time, by showing how more rapid governance evolutions are embedded in slow evolutions of the pattern of couplings between the different function systems that constitute society. We thus distinguish between the external pattern of couplings and the internal shifts in 
the configurations of actors and institutions and power/knowledge that both play a role in the evolution of governance. Building on this distinction, we thereafter discuss five key points in the interweaving of legal functions that can help to better grasp the relations between planning and law in evolving governance.

\subsection{External couplings and the functions of law in planning}

In western societies, the slow differentiation of politics, economy and the law since the Renaissance has to be considered an important context for explaining the evolution of planning and the roles of law in planning (Seabright 2010; Greif 2006; Stichweh 2000; Luhmann 1990). Planning in this context is an activity affecting land that can be treated as an object with political importance, with economic value, and with a legal definition, and these three aspects can be considered separately (McDowell 2002; Greif 2006; Pottage 2004; Adams 1994). Capitalist democracy can be considered a name for functional differentiation: the separation of powers enables the autonomous reproduction of law, politics and economy, while maintaining their coupling. As a system of politics evolves, its specific path of co-evolution with law and economy will delineate evolving spaces for planning (Van Assche et al. 2014). In a democracy, the term itself is constantly redefined, and this entails shifting boundaries with law and economy (Stichweh 2000; Delaney et al. 2001). Certain forms of planning can appear as more or less legal, more or less economically beneficial, and the tools and methods of support or contestation of planning will change. This includes the roles of law in planning.

Whether a democratic polity sees itself as a collection of individuals, a collection of organizations, a collection of tribes, or as one community, the internally developed semantics of politics will have effects on the boundaries with law and economy (Thelen 1999; Luhmann 
1995), the spaces for planning (Van Assche and Verschraegen 2008), and the roles of law in planning (Easterly 2006; North 2005; de Soto 2000). A polity as a collection of individuals (liberal democracy) will tend to develop a legal system based on individual rights, and these can strongly delimit planning (Waterhout et al. 2013). A polity based on organizations can develop enabling and delimiting functions in different directions, according to the imagined relationship between the state, for-profit organizations and non-profit organizations (Mansuri and Rao 2012; Hillier 2002; Scott 1998). Codification will follow different paths depending on whether the polity sees itself as unity or as a community, the internal variation of voices that is seen as natural and normal (socialism vs. social democracy), and the accepted role of experts in administration (Bishwapriya 2012; Verdery 2003). If the polity imagines itself as a strong state with strong citizens, active as individuals and in organizations, one can predict strong enabling and delimiting functions, and a cultivation of internal conflict in planning (Jacobs 2004; Von Benda-Beckman 2002; Mehrhoff 1999).

While external couplings evolve, and communities change identity in terms of models of democracy and thus functions of law, one can consider these evolutions primarily as longue duree, as slow evolutions embedding more rapid patterns. To grasp most of the visible shifts in the functions of law in planning, we argue, is to grasp these more rapid changes, and these changes are internally driven.

\subsection{Governance evolutions and the functions of law in planning}

Besides the external coupling of politics, law and economy, internal changes in governance influence the space for planning and alter the relation between the three functions of law in 
planning. Changes in governance can be shifts in the inclusion/exclusion of actors, topics, expertise and institutions in collective decision- making.

One can make a comparison with music, or any form of art, where the history of society at large (with its structure of classes, patterns of consumption, education, etc.), the history of music and the development of the individual composer enable the interpretation of a particular composition. Similarly, in planning, the talent of the individual planner (or designer), the history of planning (and governance) and the history of a broader context of couplings between law, politics and economy co- determine what kind of plans are produced and what their effects are.

The history of planning and, more broadly, governance, may be understood as a history of responses to previous states of the governance system, with certain actors, institutions, documents, coalitions, methods, domains and pieces of expertise taking on privileged positions in the collective decision- making on spatial organization. One can distinguish between the actual role of certain actors and their desired role and between different narratives on the structure and goal of the whole planning game.

Each step in the evolution of governance has to refer to the previous ones. This form of path dependence can also be called, with Luhmann, self-reference (Luhmann 1995). New plans and planning policies only mean something against the horizon of a history of planning, where they find things to build on and things to distinguish from, i.e. expertise to adopt or reject; positions of power to assume, strive for or reject, plans and approaches to follow or reject, as well as individuals to imitate or from which to distance themselves. These self-referential governance evolutions, together with the more slowly evolving external couplings, shape the spaces for planning. If there were no planners in the past, and if the actors involved in governance are not aware of 'planners' in other places, this has implications for the next step in spatial governance. 
It is not a neutral background. If there were many planners in a socialist past, but the whole socialist system is currently despised, this too has consequences (Hayoz and Giordano 2013). If there are planners working in administration, but strongly associated with one political party, an ousting of that party from government can effectively marginalize the planners, and reduce the influence of plans (as in Belgium (Leinfelder and Allaert 2010). In the more extreme case of government overthrow following armed conflict, the planners affiliated with the previous government may in fact have fled the jurisdiction along with many other politicians and government workers (Brown et al. 2013; Easterly 2006). If, on the other hand, there are planners and they are commonly associated with common goods and shared goals in the community, their presence and influence might be accepted more easily, even after political shifts and shocks (Othengrafen and Reimer 2013). If there is a history of such acceptance, with other actors in society making them part of their calculations (developers arguing for example not against planning as such, but against the features of this or that plan), then the reproduction of planning will tend to be easier (Bishwapriya 2012; Luhmann 1990).

A similar reasoning can be followed for forms of plans, designs, expertise, and for the scale of planning that is likely to be accepted in a certain society. If, in a small American town, infrastructure planning is the only form that is commonly accepted, perhaps under the heading of 'public works', then new plans will probably have a better chance of success if they are presented as an extension of public works programs, as a priority for a respected public works department, and clearly distinguished from other, more suspicious, forms of planning (Elliott 2008). A conservation design underpinning a comprehensive plan for a small town in the marshes can then be presented not as design but as management of water, slow traffic flows, and perhaps game, and as, indeed, a logical extension of the network approach underlying existing 
public works procedures (Radomski and Van Assche 2014; Arendt 1999; Mehrhoff 1999). If, in a post-Soviet rural community, soil quality (bonitet) is supposedly the keystone of all planning efforts (determining not only the choice of crops but also the location of villages, neighborhoods and infrastructure), and if this particular Soviet planning mythology is still cherished, it seems advisable for new planners to present new initiatives as compatible with this approach (Allina Pisano 2008).

\subsection{Key points in the interweaving of legal functions}

We can derive several key points from these scenarios, to further develop our thesis on the interweaving of legal functions in changing governance. First of all, delimitation can take place in many ways besides individual property rights. More broadly, one cannot place property rights and planning in direct opposition to each other, since property rights, as bundles of permitted and prohibited uses, can also be written to coordinate land use; i.e. to do planning (Cole and Grossman 2002; Bromley 1991). However if property rights are strong, it is likely that little planning by means of plans and designs will take place unless there is sufficient latitude provided by enabling laws.

Second, codification of plans as law is not a fail- proof way to ensure implementation. This is all the more true when codified plans proliferate, meaning that it becomes less realistic to follow all the rules and more likely to selectively interpret them. If plans are not codified as law, but they do proliferate, selectivity becomes even harder to avoid. This selectivity can be used to undermine collective goods, but it can also bring them closer: it can be a precondition for necessary flexibility, for efficiency and local democracy. Codification tends to reduce flexibility; generalized codification reintroduces it. 
Third, 'implementation' is not a step but a process. It does not magically follow from the production of plans, even though law can enable and even codify the plan. Implementation usually entails the movement of the plans through other organizations, where they may be adapted or halted (Seidl 2005). If the plans are complex and ambitious, they will be sensitive to political changes at various levels and sensitive to governance evolutions. If large scale political changes occur, and the couplings between law, economy and politics shift, this can have profound effects on plan implementation (cf. Waterhout et al. 2013; Donovan 2008; Delaney et al. 2001). The implementation of a specific plan can, in evolving governance, become a symbol for an approach to planning, or to governance in general, that is not desirable ('a bridge to nowhere', 'a useless ugly prestige project', or 'a park for drug addicts'). If that is the case, the focus will shift to delimiting laws, e.g. property rights (as in the US), or administrative law (as in Europe) (Othengrafen and Reimer 2013; Needham 2006).

Fourth, shelving of plans or non- implementation, can be done intentionally (no funds, political shift, different expertise becomes prominent), or by accident (e.g. when spontaneous implementation is expected). If plans become dead institutions, their revival is possible, but subject to the conditions of the new situation. An old plan can either be hailed as ingenious, full of foresight, or simply passé. In reviving dead institutions, an old codification as law can be helpful and can possibly avert the discussion on lacking enabling laws. In common law traditions, as in the US, the continuous reinterpretation of constitutional boundaries, of both delimiting and enabling laws, tends to make revival of dead institutions harder because the whole legal context is continuously changing (Reynolds 2010).

Lastly, each community's governance evolution is marked by a different dialectics of formal and informal institutions. We count both plans and laws as formal institutions. The next step in 
governance, in the use of plans and laws, hinges on not only the previous set of laws and plans, but also on the previous set of informal coordination mechanisms. These include informal rules of interpreting, selecting, and ignoring laws and plans. Formal and informal institutions continuously shape each other, and their interplay has profound effects on implementation of formal institutions and the different roles of law in planning.

\section{Conclusion and discussion}

This exploration shows that planning always functions in a society that determines its content, procedures and limits. Within society law is simultaneously a brake and an accelerator for planning. It is part of every toolbox for changing the planning system and at the same time part of the built-in resistance against change.

We argue that the forms of coordination that are possible in a given community depend on the pattern of differentiation of the function systems most important to planning: politics, law and economy. These relations are bound to differ in each community because of a different developmental path. Yet, even more than these slow evolutions, the embedded patterns of rapid evolution that have the most explanatory value in questions of law and planning, are evolutions internal to the system of governance. Shifts in planning are shifts in governance, in the selection of actors, institutions, expertise, documents in collective decision- making on spatial organization. Changes in any of these elements refer to the previous state of governance, and can only be understood if their conformity with or deviation from that previous state has been grasped. In that sense, governance evolution is self- referential and changing functions of law in spatial governance emerge in such a history of self- reference. 
We propose to distinguish three general roles of law in planning: enabling, delimiting and codifying. The empirical manifestation of these roles, their relative importance, and the web of interactions and feedback loops spring from the pattern and path of differentiation of function systems, and from the self- referential history of governance. Histories of strong delimitation and of precise enabling of generalized codification, of unused enabling or of delimitation and posthoc enabling require analysis as they reveal paths that change slowly and path-specific transformation mechanisms. Understanding these histories is demanding, since the continuous interaction of formal institutions (such as laws and plans) and informal institutions has to be envisioned. The effects of laws and plans and the changing appearances of law in planning are co- determined by the informal aspects of governance evolution.

The self-referentiality of governance evolutions, added to the rigidity of the couplings between the function systems law, politics and economics, does not allow for a radical reinvention of planning in a tabula rasa fashion (Valverde 2011). New forms of planning, and accordingly new roles of law in planning, are only implementable and enforceable if political, legal and economic calculations can continue (Teubner 1997). That means that planning can only coordinate spatial decision-making when it gives a space for the political game to continue, to negotiate land use and value extraction, and when it gives space for the economic game to continue, to calculate value and compete for space (Patashnik 2003; cf. Rosenberg 1991). This is only possible when the legal system can operate consistently with its own rules of reproduction. If the political system imposes a new form of plan that is not consistent with other laws that encapsulate other values and established rights, then the new plans and planning laws can be shot down by higher courts. It may also introduce an inconsistency in legal decision-making that jeopardizes the function of the legal system, by making it less predictable for the environment. 
In times of political transition, the roles of law in planning require adjustment, but the intensity and nature of the resistance to change, as well as the disruptive implications of change, hinge on the path of governance evolution and external differentiation. Thus, in one case it might be easy to reinvent planning, using law here, changing or circumventing it there, while in other cases the use of law in planning reform can destabilize society and create a variety of political, legal and economic problems. Luhmann (1990), Rosenberg (1991), Ferguson (1994) and Easterly (2006) and their many co- travelers, in their rather cynical stance towards laws and other formal institutions as bringers of change, of desirable development, are often right, it seems, but Acemoglu and Robinson's (2012) seemingly simple (institutionalist- inspired) claim for the importance of rule of law in development still holds just as much truth. Our proposal to distinguish between delimiting, enabling and codifying roles of law in planning, and on the interplay between the three in both policy formation and implementation, can be helpful in elucidating empirical governance evolutions. It can also be helpful in avoiding the pitfalls of ideologically inspired dichotomies (such as planning vs. law; searchers vs. planners; formal vs. informal), which clearly do not lead to theoretically and practically desired places.

\section{References}

Adams D (1994) Urban planning and the development process. UCL Press, London Allina - Pisano J (2008) Post Soviet Potemkin villages. Politics and property rights in the black earth. Cambridge University Press, Cambridge

Allmendinger P (2002) Planning theory. Palgrave, Basingstoke

Arendt RG (1999) Growing greener. Putting Conservaiton into Local Plans and Ordinances. Island Press, Washington

Assche K, van (2006) Over goede bedoelingen en hun schadelijke bijwerkingen: essay over flexibiliteit, ruimtelijke ordening en systeemtheorie. InnovatieNetwerk, Utrecht

Beunen R (2010) The governance of nature: how nature conservation ambitions have been dashed in planning practices. Wageningen University, Wageningen 
Beunen R, Duineveld M (2010) Divergence and Convergence in Policy Meanings of European Environmental Policies: The Case of the Birds and Habitats Directives. International Planning Studies 15 (4):321-333. doi:10.1080/13563475.2010.517379

Beunen R, Van Assche K (2013) Contested delineations: planning, law and the governance of protected areas. Environment and Planning A 45 (6):1285-1301

Binelli M (2012) Detroit City is the Place to Be: The Afterlife of an American Metropolis Henry Holt and Co, New York

Bishwapriya S (ed) (2012) Comparitve Planning Cultures. Routledge, New Yrok

Blaesser BW, Weinstein AC (eds) (1989) Land Use and the Constitution. American Institute of Certified Planners, Chicago

Blomley NK, Clark GL (1990) Law, theory, and geography. Urban Geography 11 (5):433-446

Bohannan P (1969) Etnography and comparison in legal anthropology. In: Nader L (ed) Law in Culture and Society. University of California Press, Berkely, pp 401-418

Braverman I (2011) Hidden in plain view: legal geography from a visual perspective. Law, Culture and the Humanities 72 (2):173-186

Bromley D (1991) Environment and Economy: Property Rights and Public Policy. Blackwell, Cambridge MA

Brown HCP, Smit B, Somorin OA, Sonwa DJ, Ngana F (2013) Institutional perceptions, adaptive capacity and climate change response in a post-conflict country: a case study from Central African Republic. Climate and Development 5 (3):206-216

Cole DH, Grossman PZ (2002) The Meaning of Property Rights: Law vs. Economics. Land Economics 78 (3):317-330

Conley JM, O'Barr WM (1993) Legal anthropology comes home: A brief history of the ethnographic study of law. Loyola of Los Angeles Law Review 27 (1):40-64

Dalla Longa R (2011) Urban Models and Public-Private Partnership. Springer, Heidelberg

de Soto $\mathrm{H}$ (2000) The mystery of capitalism: why capitalism triumphs in the west and fails everywhere else. Basic Books, New York

Delaney D, Blomely NK, Ford RT (eds) (2001) The legal geographies reader: law, power, and space. Blackwell Publishers, Oxford

Djanibekov U, Van Assche K, Boezeman D, Djanibekov N (2013) Understanding contracts in evolving agro-economies: Fermers, dekhqans and networks in Khorezm, Uzbekistan. Journal of Rural Studies 32:137-147. doi:10.1016/j.jrurstud.2013.05.003

Donovan JM (2008) Legal anthropology: an introduction. Altamira Press, Lanham

Duineveld M (2006) Van oude dingen, de mensen, die voorbij gaan. Over de voorwaarden meer recht te kunnen doen aan de door burgers gewaardeerde cultuurhistories. Eburon, Delft

Duineveld M, Beunen R, Van Assche K, During R, Ark R, van. (2009) The relationship between description and prescription in transition research. In: Poppe KJ, Termeer C, Slingerland M (eds) Transitions towards sustainable agriculture and food chains in peri-urban areas. Wageningen Academic Publishers, Wageningen, p 392 
Duineveld M, Van Assche KAM, Beunen R (2013) Evolutionary governance theory and the production of space. Irreversibility, object formation and stabilisation and in urban governance. Wageningen University Working Papers in Evolutionary Governance Theory 11

Easterly W (2006) The white man's burden: why the West's efforts to aid the rest have done so much ill and so little good. Oxford University Press, Oxford

Ellickson R (1991) Order without law. How neighbors settle disputes. Harvard University Press, Cambridge

Elliott D (2008) A better way to zone: ten principles to create livable cities. Island Press, Washington

Ferguson J (1994) The Anti-politics Machine: "development", Depolicization, and Bureaucratic Power in Lesotho. University of Minnesota Press, Minneapolis

Fischel WA (1987) The Economics of Zoning Laws. A Property Rights Approach to American Land Use Controls. The Johns Hopkins University Press, Baltimore

Fischler R (1998) Toward a genealology of planning: zoning and the Welfare State. Planning Perspectives 13:389-410

Ford K (2010) The trouble with city planning: What New Orleans can teach use. Yale Univerity Press, New Haven

Gallagher J (2010) Reimagining Detroit: Opportunities for Redefining an American City. Wayne State University Press, Detroit

Gel'man V (2004) Unrule of Law in the Making: the Politics of Informal Institution Building in Russia. Europe-Asia Studies 56 (7):1021-1040

Gerber E (1999) Gerber, E. 1999. The populist paradox: interest group influence and the promise of direct legislation. Princeton University Press, Princeton

Greif A (2006) Institutions and the path to the modern economy: Lessons from medieval trade. Cambridge University Press, Cambridge

Grossfeld B (1983) Geography and law. Michigan Law Review 82 (5/6):1510-1519

Hayoz N, Giordano C (2013) Informality in Eastern Europe. Peter Lang, Frankfurt

Hillier J (2002) Shadows of power: an allegory of prudence in land-use planning. Routledge, New York

Jacobs H (ed) (2004) Private Property in the 21st Century: The Future of an American Ideal Edward Elgar, Cheltenham

King M, Thornhill E (2003) Niklas Luhmann's theory of politics and law. Palgrave Macmillan, Basingstoke

Leinfelder H, Allaert G (2010) Increasing societal discomfort about a dominant restrictive planning discourse on open space in Flanders, Belgium. European Planning Studies 18 (11):1787-1804

Luhmann N (1990) Political theory in the welfare state. Mouton de Gruyter, Berlin

Luhmann N (1995) Social systems. Stanford University Press, Stanford

Luhmann N (2004) Law as a social system. Oxford University Press, Oxford

Makielski SJ (1966) The Politics of Zoning: The New York Experience. Columbia University Press, New York

Mansuri G, Rao V (2012) Localizing development: does participation work? The World Bank, Washington

McDowell A (2002) From Commons to Claims: Property Rights in the California Gold Rush. Yale Journal of Law \& the Humanities 14 (1):34-39 
Mehrhoff WA (1999) Community Design: A Team Approach to Dynamic Community Systems. Sage Publication, Thousand Oaks

Needham B (2006) Planning, Law and Economics. An investigation of the rules we make for using land. Routledge, London

North DC (2005) Understanding the process of economic change. Princeton University Press, Princeton

Ohm BW (2000) Reforming Land Planning Legislation at the Dawn of the 21st Century: The Emerging Influence of Smart Growth and Livable Communities. Urban Law $32: 181$

Ostrom E (2005) Understanding institutional diversity. Princeton University Press, Princeton

Othengrafen F, Reimer M (2013) The embeddedness of planning in cultural contexts: theoretical foundations for the analysis of dynamic planning cultures.

Environment and Planning A 45 (6):1269-1284

Patashnik E (2003) After the public interest prevails: The political sustainability of policy reform. Governance 16 (2):203-234

Peterson J (2003) The Birth of City Planning in the United States. Johns Hopkins University Press, Baltimore

Platt RH (2004) Land use and society : geography, law, and public policy. Rev. edn. Island Press, Washington

Posner RA (2003) Law, pragmatism, and democracy. Harvard University Press, Cambridge, Mass. ; London

Pottage A (2004) The fabrication of persons and things. In: Pottage A, Mundy M (eds) Law, anthropology and the constitution of the social. Making persons and things. Cambridge University Press, Cambridge, pp 1-39

Radomski P, Van Assche K (2014) Lakeshore Living Designing Lake Places and Communities in the Footprints of Environmental Writers. Michigan State University Press, East Lansing

Reynolds S (2010) Before eminent domain: towards a history of expropriation of land for the common good. UNC Press, Chapel Hill

Rosenberg GN (1991) The hollow hope : can courts bring about social change? University of Chicago, Chicago ; London

Salet WG, Thornley A, Kreukels A (eds) (2003) Metropolitan governance and spatial planning: comparative case studies of European city-regions. Taylor \& Francis, London

Schlager E, Ostrom E (1992) Property-rights regimes and natural-resources. A conceptual analysis. Land Economics 68 (3):249-262

Scott JC (1998) Seeing Like a State: How Certain Schemes to Improve the Human Condition Have Failed. Yale agrarian studies. Yale University Press, New Haven

Seabright P (2010) The company of strangers: a natural history of economic life. Princeton University Press, Princeton

Seidl D (2005) Organizational identity and self- transformation. An autopoietic perspective. Ashgate, Aldershot

Stallworthy M (2002) Sustainable land use and the environment, a legal analysis. Cavendish, London 
Stein R (2009) Rule of Law: What does it mean? Minnesota Journal of International Law 18:293

Stichweh R (2000) Die weltgesellschaft. Soziologische analysen. Suhrkamp, Frankfurt Teubner G (ed) (1988) Autopoietic Law: A New Approach to Law and Society. Walter de Gruyter, Berlin

Teubner G (1989) How the Law Thinks: Towards a Constructivist Epistemology of Law. Law \& Society Review 23 (5):727-758

Teubner G (1997) The King's many bodies: The self-deconstruction of Law's hierarchy. Law \& Society Review 31 (4):763-788

Thelen K (1999) Historical institutionalism in compartive politics. Annual review of political science 2 (1):369-404

Valverde M (2011) Seeing Like a City: The Dialectic of Modern and Premodern Ways of Seeing in Urban Governance. Law \& Society Review 45 (2):277-312

Van Assche K, Beunen R, Duineveld M (2012a) Formal/Informal Dialectics and the SelfTransformation of Spatial Planning Systems: An Exploration. Administration \& Society Online First. doi:10.1177/0095399712469194

Van Assche K, Beunen R, Duineveld M (2012b) Performing Success and Failure in Governance: Dutch Planning Experiences. Public Administration 90 (3):567-581. doi:10.1111/j.1467-9299.2011.01972.x

Van Assche K, Beunen R, Duineveld M (2014) Evolutionary Governance Theory: An Introduction. Springer Briefs in Economics. Springer, Heidelberg

Van Assche K, Beunen R, Jacobs J, Teampau P (2011) Crossing trails in the marshes: rigidity and flexibility in the governance of the Danube Delta. Journal of Environmental Planning and Management 54 (8):997-1018. doi:10.1080/09640568.2010.547687

Van Assche K, Djanibekov N (2012) Spatial planning as policy integration: The need for an evolutionary perspective. Lessons from Uzbekistan. Land Use Policy 29 (1):179-186. doi:10.1016/j.landusepol.2011.06.004

Van Assche K, Shtaltovna, A., Hornidge, A-K (2013) Visible and invisible informalities and institutional transformation. Lessons from transition countries: Georgia, Romania, Uzbekistan. In: Hayoz N, Giordano C (eds) Informality and postsocialist transition Peter Lang, Frankfurt,

Van Assche K, Verschraegen G (2008) The Limits of Planning: Niklas Luhmann's Systems Theory and the Analysis of Planning and Planning Ambitions. Planning Theory 7 (3):263-283

van Dijk T, Beunen R (2009) Laws, People and Land Use: A Sociological Perspective on the Relation Between Laws and Land Use. European Planning Studies 17 (12):1797-1815. doi:10.1080/09654310903322314

Verdery K (2003) The vanishing hectare: property and value in postsocialist Transylvania. Cornell University Press, Ithaca, N.Y. ; London

Von Benda-Beckman F (2002) Who's Afraid of Legal Pluralism? Journal of Legal Pluralism 47:37-83

Waterhout B, Othengrafen F, Sykes O (2013) Neo-liberalization processes and spatial planning in France, Germany, and the Netherlands: an exploration. Planning Practice \& Research 28 (1):141-159 
Waters CP (2005) Post-conflic Legal Eduation. Journal of Conflict and Security Law 10 (1):109-119 